\title{
THE PROFILE OF FATTY ACIDS AND THE EGGS QUALITY FROM HENS FED TO THE DIET WITH FLAX SEEDS, RAPESEED MEAL AND VITAMIN E SUPPLEMENTS
}

\author{
Petru Alexandru VLAICU ${ }^{1, *}$, Tatiana Dumitra PANAITE ${ }^{1}$, \\ Raluca Paula TURCU ${ }^{1}$, Gabriela Maria CORNESCU ${ }^{1}$, \\ Petruța VIȘINESCU ${ }^{2}$ \\ *E-mail: alexandru.vlaicu@outlook.com
}

Received: Nov. 09, 2021. Revised: Dec. 04, 2021, Accepted: Dec. 10, 2021, Published online: Jan. 25, 2022

\begin{abstract}
This experiment investigates the effect of flaxseed meal, rapeseed meal and vitamin E supplementation, when used together, on the production parameters of fatty acid composition and eggs quality characteristics in Tetra SL laying hens (38 to 46 weeks of age). For this, 120 hens were allocated one of three treatments, with 40 hens in each group. The hens were fed either a control diet (C), a control diet including $2.5 \%$ flaxseed meal and $2.5 \%$ rapeseed meal (E1) or $2.5 \%$ flaxseed meal and $2.5 \%$ rapeseed meal with $73 \mathrm{mg} / \mathrm{kg}$ feed of vitamin $\mathrm{E}$ as an antioxidant supplement (E2) for 8 weeks. Hens consuming the E1 diet had greater egg production and egg mass than those from group $\mathrm{C}$. The feed conversion ratio in both the $\mathrm{E} 1$ and $\mathrm{E} 2$ groups was lower $(\mathrm{P}<0.05)$ than in the $\mathrm{C}$ diet group. $\mathrm{E} 2$ had considerably higher egg weight, albumen $\mathrm{pH}$, yolk $\mathrm{pH}$ and Haugh unit than $\mathrm{E} 1$ and $\mathrm{C}$ (P0.05), as a response to the vitamin $\mathrm{E}$ antioxidant effect. The most $\alpha$-linolenic fatty acid content (1.07 g FAME) was found in eggs produced by chickens fed the E2 diet, (1.07 g FAME), followed by E1 (0.91 g FAME), with both being significantly higher than $\mathrm{C}$ eggs
\end{abstract}

(0.23g FAME). Furthermore, all n-6 studied fatty acids concentrations were significantly lower $(\mathrm{P}<0.05)$ in $\mathrm{E} 1$ and $\mathrm{E} 2$, while all n-3 fatty acids concentrations were significantly greater $(\mathrm{P}>0.05)$ in $\mathrm{E} 1$ and $\mathrm{E} 2$. When comparing the n-6/n-3 ratio of fatty acids from experimental treatments (6.44 and 6.74) with C treatment (18.19), a significant difference was observed (almost 65\% lower).

Keywords: egg fatty acids; egg quality; flaxseed; laying hens; rapeseed.

\section{INTRODUCTION}

Laying hen eggs, original and natural foods, are an important component of human nutrition.

The food provided to the birds greatly influences the fatty acid profile of the eggs, which use a large part of the ingested acids for the deposition of the yolk. Given the health benefits of n-3 fatty acids, scientists have focused on conducting research to enrich eggs with those beneficial fatty acids and meet

\footnotetext{
${ }^{1}$ National Research and Development Institute for Animal Biology and Nutrition, Baloteşti, llfov County, Romania 2 SC Avitor SRL, Călăraşi County, Romania
} 
consumer requests (Ao et al., 2015; Lordelo et al., 2017).

The most commonly known, functional food is the polyunsaturated fatty acid (PUFA)-enriched eggs that are a topic of continued interest (FAO, 2010). Such eggs are produced by laying hens that are fed with various sources of PUFA, like flaxseed meal (FM) or rapeseed meal (RM) (Fraeye et al., 2012), with or without natural or synthetic antioxidants (i.e., vitamins).

Flaxseed meal (Linum usitatissimum) has a high content of proteins (22\%), lipids (43\%) and minerals (3\%) with a high concentration of $\alpha$-linolenic fatty acid ( $37 \%$ to $60 \%$ ), which represents the main characteristic of the by-products (Rahimi et al., 2014). For these reasons, flax is making its mark in the world's food and feed supply as a functional food, by delivering health benefits, serving as the best source of n-3 for non-fish eaters. Rapeseed meal (Brassica rappa) is generally rich in protein $(33 \%$ to $40 \%)$, scarce in lysine, but higher in methionine and cysteine. Rapeseed also contains higher crude fibre when unlike with soybean meal or flaxseed. In monogastric nutrition RM has limited usage because it has a low energy content and because it contains antinutritional factors (Khajali et al., 2012).

Under conditions of moderate amounts of 150 to $200 \mathrm{~g} / \mathrm{kg}$ of diet, no adverse effects were found on the growth of the chicken (Ahmad et al., 2007). Gheorghe et al. (2019) summarised the implications of FM and RM in poultry nutrition, presenting the numerous beneficial effects of PUFA in diets and its implication in poultry nutrition.

The most important antioxidant contained in yolk lipids is vitamin E, which completes the lipid peroxidation chain, stabilizing lipid peroxides (Dominguez et al., 2019).

Lukaszewicz et al. (2007) found a decrease in fat content due to increased protein levels, as well as antioxidant properties, as an effect of vitamin E. Sigolo et al. (2019) find that vitamin E promotes growth performance in poultry.

For human nutrition, fatty acids and antioxidants contained in eggs are particularly important, at least in terms of total PUFA and n-3 fatty acids. Feeding laying hens diets that are rich in PUFA, through dietary manipulation, strongly influences egg composition (King et al., 2012) by positively influencing several nutrients with important health implications (Vlaicu et al., 2021).

The scientific investigations carried out aimed to highlight the influence of administering $\mathrm{RM}$ and $\mathrm{FM}$ in poultry feed as natural sources of PUFA, with or without synthetic vitamin E, as a source of antioxidant, on the productivity of laying hens, the eggs quality and the yolk fatty acid profile.

\section{MATERIALS AND METHODS}

\section{Ethical statement}

Care was taken in the animal use in this study, which was conducted according to the experimental protocol no.1250/ 28.02.2019, approved by our Ethical Committee according to Directive 2010/63/EU. The researches were performed at National Research and Development Institute for Animal Biology and Nutrition, Balotesti, Romania.

\section{Bird management and housing}

A number of 120 laying hens of the Tetra SL breed, aged 9 and a half months, were arranged randomly, 4 in 30 enclosures 


\section{PROFILE OF FATTY ACIDS AND THE EGGS QUALITY FROM HENS FED WITH FM AND RM}

each. Each cage (pen) was considered to be an experimental unit. The Zucami-type cages, sized so as to comply with the sanitary-veterinary norms, were placed in an experimental hall. Through a Viper Touch computer, the environmental factors were maintained at the following parameters: temperature $20.78 \pm 1.5^{\circ} \mathrm{C}, \quad$ humidity $52.11 \pm 3.05 \%$ and ventilation $3.55 \pm 0.37 \%$.

\section{Experimental treatments}

The study was performed in three experimental diet variants: C (control); E1 (2.5\% FM and $2.5 \% \mathrm{RM})$; and E2 (2.5\% FM and $2.5 \% \mathrm{RM}$ with $73 \mathrm{mg} / \mathrm{kg}$ of premixed vitamin E supplement). The 8\% sunflower meal from the $\mathrm{C}$ diet was completely replaced in experimental diets with FM and RM, to meet the nutritional requirements of Tetra SL LL (Management Breeding Guide, 2019).

The vitamin E supplement was only added in the vitamin-mineral premix of the E2 diet. Diets - isocaloric and isonitrogenous - were applied ad libitum during the eight experimental weeks, as presented in Table 1.

\section{Parameters of performance}

Feed intake (FI) (g feed/hen), laying rate $(\%)$, egg mass $(\mathrm{g})$ and feed conversion rate (FCR) $(\mathrm{kg}$ feed $/ \mathrm{kg}$ egg) were established each day. Egg mass was established with an appropriate formula.

\section{Obtaining and preparing samples}

Proximal determinations of the chemical composition were performed on samples of $500 \mathrm{~g}$ of raw materials and diets for each treatment variant. The analyzes were performed in compliance with the provisions stipulated by the Association of Official Analytical Chemists. At the end of the experimentation period, the quality of the eggs was assessed based on the specific parameters.

For the 18 eggs chosen at random from those obtained in each diet, the mass of eggs and yolks, the mass and thickness of the shell, the Hauch units and the color of the yolks were established and appreciated, respectively.
Table 1 - Dietary ingredients and nutrients

\begin{tabular}{llll}
\hline $\begin{array}{l}\text { Ingredients, } \\
\% \text { as feed basis }\end{array}$ & C & E1 & E2 \\
\hline Corn & 53.74 & 55.84 & 55.84 \\
\hline Soybean meal & 23.85 & 25.64 & 25.64 \\
\hline Sunflower meal & 8.00 & - & - \\
\hline Flaxseed meal & - & 2.50 & 2.50 \\
\hline Rapeseed meal & - & 2.50 & 2.50 \\
\hline Vegetable oil & 2.70 & 1.76 & 1.76 \\
\hline DL Methionine & 0.12 & 0.14 & 0.14 \\
\hline CaCO & 8.79 & 8.76 & 8.76 \\
\hline Monocalcium Phosphate & 1.35 & 1.41 & 1.41 \\
\hline Choline & 0.05 & 0.05 & 0.05 \\
\hline Salt & 0.40 & 0.40 & 0.40 \\
\hline Mineral and vitamin & $1.00^{*}$ & $1.00^{*}$ & $1.00^{* *}$ \\
\hline premix & 100 & 100 & 100 \\
\hline Total & & & \\
\hline Nutrient analysis & 2800 & 2800 & 2800 \\
\hline Metabolisable & 17.80 & 17.80 & 17.80 \\
\hline energy, kcal/kg & 4.46 & 3.81 & 3.81 \\
\hline Crude protein, \% & 4.75 & 3.40 & 3.40 \\
\hline Crude fat, \% & 3.90 & 3.90 & 3.90 \\
\hline Ca, \% & 0.63 & 0.66 & 0.66 \\
\hline P, \% & 0.38 & 0.38 & 0.38 \\
\hline Av. Phosphorus, \% & 0.89 & 0.92 & 0.92 \\
\hline L-lysine-HCL, \% & 0.42 & 0.42 & 0.42 \\
\hline Methionine, \% & 0.73 & 0.73 & 0.73 \\
\hline Meth + Cist, \% & 0.68 & 0.68 & 0.68 \\
\hline Threonine, \% & 0.20 & 0.19 & 0.19 \\
\hline Tryptophan, \% & & & \\
\hline & & & \\
\hline
\end{tabular}

* For every kilogram of $C$ and $E 1$ diets the premix is assured $13.500 \mathrm{IU}$ vitamin $\mathrm{A} ; 3.000 \mathrm{IU}$ vitamin D3; $27 \mathrm{mg}$ vitamin E; $2 \mathrm{mg}$ vitamin $\mathrm{K} 3 ; 2 \mathrm{mg}$ vitamin B1; $4.8 \mathrm{mg}$ vitamin B2; $14.85 \mathrm{mg}$ pantothenic acid; $27 \mathrm{mg}$ nicotinic acid; $3 \mathrm{mg}$ vitamin B6; $0.04 \mathrm{mg}$ vitamin B7; $1 \mathrm{mg}$ vitamin B9; $0.018 \mathrm{mg}$ vitamin B12; $25 \mathrm{mg}$ vitamin $\mathrm{C} ; 71.9 \mathrm{mg}$ manganese; $60 \mathrm{mg}$ iron; $6 \mathrm{mg}$ copper; $60 \mathrm{mg}$ zinc; $0.5 \mathrm{mg}$ cobalt; $1.14 \mathrm{mg}$ iodine and, $0.18 \mathrm{mg}$ selenium. C - control diets; E1 - control diet $+2.50 \% \mathrm{FM}$ and $2.50 \% \mathrm{RM}$; E2 - control diet + $2.50 \% \mathrm{FM}$ and $2.050 \% \mathrm{RM}$ and $73 \mathrm{mg} / \mathrm{kg}$ feed vitamin E. ** Premix with the addition of $100 \mathrm{mg}$ vitamin $\mathrm{E} / \mathrm{kg}$ feed.

Subsequently, fatty acid content and yolks chemical composition were analyzed. The determinations were performed on six samples consisting of three yolks separated 
from eggs collected from each group of 18 hens.

\section{Chemical analysis}

The nutrient concentration was measured on dry samples at $65^{\circ} \mathrm{C}$. The Kjeldahl method was used to determine the crude protein $(\mathrm{CP})$ and the crude fat $(\mathrm{EE})$ was determined by extraction into organic solvents.

To determine the crude fiber (CF) content, the intermediate filtration process was used, as regulated in the SR EN ISO 6865: 2002 standard. All assays were carried out in compliance with the provisions of Regulation (EC) no. 152/2009.

\section{Egg quality parameters}

The mass of the egg white, yolk and shell were measured with a Kern precision balance. The establishment of the Haugh unit was done with the help of an Egg Analyzer TM. Eggshell thickness and breaking strength were measured with specific equipment produced by Sanov.

The $\mathrm{pH}$ values of the egg white and yolk were determined with the WTW InoLab $\mathrm{pH}$ meter and the color of the yolk with the Roche yolk color fan produced by HoffmanLa Roche Ltd.

\section{Yolk fatty acids determination}

The fatty acid composition of the yolks, plants and feeds was determined with a Perkin-Elmer Clarus 500 gas chromatograph. Considering the average values of each fatty acid, the amount of total saturated fatty acids (SFA), total monounsaturated (MUFA) and total polyunsaturated (PUFA) was calculated.

\section{Statistical analysis}

The assessment of the effect of the diets applied on the performance indices of the hens and the composition of the eggs was made on the basis of the unidirectional analysis of the variance (ANOVA). Based on the Tukey test with multiple intervals, the significance between the individual media was determined. For $(p)$ values less than 0.05 the mean differences were considered significant.

\section{RESULTS AND DISCUSSION}

\section{Chemical composition \\ of flaxseed and rapeseed meal}

The average proximate chemical composition of FM and RM are presented in Table 2. Each of these two by-products is an important source of protein and fat, and it should be noted that FM had the highest level of ether extract (EE), while RM had the highest level of crude fibre (CF).Moreover, rapeseed is the second protein source after flaxseed, having a higher essential amino acids content. Both presented comparable values for dry matter (DM), organic matter (OM) and crude protein (CP). FM had a higher concentration of minerals like copper $(\mathrm{Cu})$ and zinc $(\mathrm{Zn})$, while RM was rich in manganese $(\mathrm{Mn})$. Both of the meals used had similar values for calcium $(\mathrm{Ca})$, phosphorus $(\mathrm{P})$ and iron $(\mathrm{Fe})$. Data in the literature for FM displays large variations of chemical composition, 29.97 to $43.30 \%$ for $\mathrm{CP}$, 1.13 to $15.69 \%$ for EE, 8.33 to $12.94 \%$ for $\mathrm{CF}$ and 3.87 to $6.40 \%$ ash (Mueller et al., 2010). Significant variation was also reported for RM: 31.15 to $38.00 \% \mathrm{CP}$, 0.85 to $3.80 \% \mathrm{EE}, 9.13$ to $15.49 \% \mathrm{CF}$ and 4.70 to $8.02 \%$ ash (Mikulski et al., 2012).

The various results for these meals, presented in the literature (Mueller et al., 2010; Sepher et al., 2021), are given by different factors, such as oil extraction process, soil, temperature, storage conditions or other influential climatic factors. 
PROFILE OF FATTY ACIDS AND THE EGGS QUALITY FROM HENS FED WITH FM AND RM

Table 2 - Composition of flaxseed meal and rapeseed meal

\begin{tabular}{|c|c|c|c|c|c|c|}
\hline \multirow{2}{*}{ Item } & \multicolumn{6}{|c|}{ Nutrients } \\
\hline & DM, \% & $\mathrm{OM}, \%$ & $\mathrm{CP}, \%$ & EE, \% & CF, \% & Ash, $\%$ \\
\hline Flaxseed meal & 90.24 & 84.95 & 34.57 & 9.79 & 8.56 & 5.29 \\
\hline Rapeseed meal & 89.08 & 82.76 & 33.79 & 2.11 & 10.99 & 6.32 \\
\hline \multicolumn{7}{|c|}{ Trace elements } \\
\hline & $\mathrm{Ca}, \%$ & $P, \%$ & $\mathrm{Cu}, \mathrm{ppm}$ & $\mathrm{Fe}, \mathrm{ppm}$ & Mn, ppm & Zn, ppm \\
\hline Flaxseed meal & 0.32 & 1.13 & 27.60 & 202.79 & 52.90 & 89.46 \\
\hline Rapeseed meal & 0.55 & 1.21 & 7.84 & 198.49 & 76.43 & 74.50 \\
\hline \multicolumn{7}{|c|}{ Fat degradation } \\
\hline & \multicolumn{2}{|c|}{ Peroxide indices } & \multicolumn{2}{|l|}{ Fat acidity } & \multicolumn{2}{|c|}{ Kreis Reaction } \\
\hline Flaxseed meal & \multicolumn{2}{|l|}{0.32} & \multicolumn{2}{|l|}{12.99} & \multicolumn{2}{|l|}{ negative } \\
\hline Rapeseed meal & \multicolumn{2}{|l|}{0.33} & \multicolumn{2}{|l|}{12.43} & \multicolumn{2}{|l|}{ negative } \\
\hline
\end{tabular}

DM - dry matter; OM - organic matter; CP - crude protein; EE - crude fat; CF - crude fiber

\section{Laying hens performances}

Data expressing the effect of experienced treatments on laying hens performance are listed in Table 3.

The use of E2 treatment, significantly decreased feed intake (FI) $(p<0.0046)$ unlike with E1. We found no significant effect for feed conversion ratio (FCR), egg weight, laying percentage or egg mass.

The results obtained from the experimental study undertaken agree with the values obtained by other researchers (Irandoust et al., 2012; Jiang et al., 2013), where no effect on egg weight and/or FCR was found.

Contrary to our results, it was recently reported that hens without supplemental vitamin $\mathrm{E}$ had a reduced ( $p$ $<0.05)$ egg mass and an increased FCR (Liu et al., 2019). Moreover, it was reported that higher levels $(10 \%)$ of flaxseed meal and camelina meal in laying hens diets significantly increased FI (Cherian et al., 2016).

Overall, the majority of reports did not indicate any relevant impact on laying hens' performance.

\section{Internal and external}

\section{egg quality characteristics}

The tested treatments did not affect the egg weight, their constituents (Table 4), shell thickness or strength of the eggs $(p>0.05)$. This illustrates that the treatments used did not result in any unfavourable side effects in eggshell quality. The yolk colour after E2 treatment, measured with a Roche colour fan, tended to be higher in E2 unlike with $\mathrm{C}$ and $\mathrm{E} 1$, but with no significant $(p>0.05)$ effect. In contrast, the Haugh unit (HU), which is a freshness parameter in eggs, was significantly higher $(p<0.0322)$ in E2 unlike with C and E1 eggs, as a main effect of the added vitamin E supplement.

Some reports showed no effects on the egg quality when laying hens were fed with $0.2 \mathrm{~g} / \mathrm{kg}$ of vitamin $\mathrm{E}$ or $0.25 \mathrm{~g} / \mathrm{kg}$ of vitamin $\mathrm{E}$ (Jiang et al., 2013). Similarly, Hayat et al. (2009) reported a significantly higher $\mathrm{HU}$ (88.83), when hens were subjected to a diet which contained 10\% FM and $50 \mathrm{IU}$ tocopherols as an antioxidant, unlike with a control diet. The lack of antioxidants (natural or synthetic) in 
laying hens diets supplemented with flaxseed or rapeseed oils could result in lower HU, as obtained by Ceylan et al. (2011). This could be a negative effect, considering the fact that PUFA-enriched eggs undergo proton to lipid oxidation, which may further affect the shelf-life of eggs.

Table 3 - Performances obtained through the experimental period (8 weeks)

\begin{tabular}{lllllc}
\hline \multicolumn{1}{c}{ Item } & C & E1 & E2 & SEM & p \\
\hline Feed intake, g/day/hen & $123.02^{\text {ab }}$ & $127.19^{\mathrm{a}}$ & $119.70^{\mathrm{b}}$ & 0.939 & 0.0046 \\
\hline Feed conversion ratio, kg feed/kg egg & 2.13 & 2.12 & 2.13 & 0.015 & 0.9742 \\
\hline Egg weight, $\mathbf{g}$ & 64.21 & 64.26 & 63.93 & 0.123 & 0.5260 \\
\hline Laying percentage, \% & 90.00 & 91.88 & 89.64 & 0.651 & 0.2010 \\
\hline Egg mass, g & 57.77 & 58.90 & 57.60 & 0.401 & 0.0935 \\
\hline
\end{tabular}

${ }^{\mathrm{a}, \mathrm{b}}$ the means marked with a different superscript letter are significantly different. $\mathrm{C}$ - control diet; E1 - control diet with 2.5\% FM and 2.5\% RM; E2 - control diet with $2.5 \% \mathrm{FM}, 2.5 \% \mathrm{RM}$ and 73 $\mathrm{g} / \mathrm{kg}$ premix vitamin E.SEM - standard error of the mean. $\mathrm{p}$ - significance

Table 4 - Egg quality characteristics

\begin{tabular}{llllll}
\hline Items & $\mathbf{C}$ & E1 & E2 & SEM & $\boldsymbol{p}$ \\
\hline Egg weight (g) & 64.73 & 65.60 & 66.49 & 0.406 & 0.2022 \\
\hline Albumen weight (g) & 38.94 & 40.00 & 40.49 & 0.437 & 0.3836 \\
\hline Yolk weight (g) & 17.20 & 17.23 & 17.51 & 0.218 & 0.8137 \\
\hline Shell weight (g) & 8.59 & 8.36 & 8.48 & 0.075 & 0.4817 \\
\hline Shell strength (kgF) & 4.25 & 4.18 & 4.03 & 0.079 & 0.5033 \\
\hline White pH & 9.08 & 9.07 & 9.12 & 0.019 & 0.4613 \\
\hline Yolk pH & 6.18 & 6.23 & 6.13 & 0.023 & 0.0522 \\
\hline Yolk colour fan & 5.77 & 5.78 & 6.33 & 0.118 & 0.0513 \\
\hline Haugh units (HU) & $86.96^{\mathrm{b}}$ & $87.08^{\mathrm{b}}$ & $91.90^{\mathrm{a}}$ & 1.021 & 0.0322 \\
\hline
\end{tabular}

The symbols used have the same meaning as in Table 3.

\section{Fatty acid composition of eggs}

Data expressing the effect of dietary treatments on yolk fatty acid composition are listed in Table 5.

The results obtained showed that the most abundant of saturated fatty acids (SFA) was palmitic acid, significantly higher $(p<0.0022)$ in variant $\mathrm{C}$ unlike to variants E1 and E2. This was followed by stearic acid which was higher in C unlike with E2 $(p<0.0192)$. Heptadecanoic fatty acid was significantly higher $(p<0.0363)$ only in the eggs obtained from hens fed in variant $E 1$. Of the total MUFA, palmitoleic acid and oleic acid recorded significantly higher values $(p<0.05)$ higher in the yolks of variants E1 and E2. Unlike to the yolks of variants E1 and E2, the yolks nervonic fatty acid content of variants $\mathrm{C}$ was significantly higher $(p<0.0001)$. The linoleic acid and arachidonic acid, which are the main n-6 fatty acids, were significantly $(p<$ $0.001)$ lower $(p<0.005)$ in both experimental treatments (E1 and E2) unlike with $\mathrm{C}$ yolks. However, of the total n-3 essential polyunsaturated fatty acids, the most important, through their involvement in human physiology, were found in the yolks obtained from hens fed in the E1 and E2 diet variants. 


\section{PROFILE OF FATTY ACIDS AND THE EGGS QUALITY FROM HENS FED WITH FM AND RM}

The docosapentaenoic, $\alpha$-linolenic and docosahexaenoic acid concentrations in E1 and E2 yolks, were two times higher unlike with $\mathrm{C}$ yolks. The hens from the E1 and E2 experimental treatments deposited significantly $(p$ $<0.001$ ) higher concentrations of n-3 PUFA into their eggs unlike to those obtained from $\mathrm{C}$ diet variant. The significant increase in $\alpha$-linolenic and docosahexaenoic fatty acids, with a concomitant decrease in linolenic and arachidonic fatty acids from E1 and E2 egg yolks unlike with $\mathrm{C}$ yolks, was also presented by others (Halle et al., 2013; Imran et al., 2015).

The variation of fatty acids (SAT, MUFA, PUFA) in eggs obtained in the three groups of laying hens is due on the one hand to the conversion of one acid to another acid (e.g., stearic acid to oleic acid) and on the other hand, to the involvement of enzymes in generating and depleting of these fatty acids.

Decreased arachidonic and linoleic acids due to desaturation and elongation of hen's liver, caused an increase of $\alpha$-linolenic, which was metabolised to long-chain n-3 fatty acids (Özkan et al., 2015). The antioxidant added (Vitamin E) has a major contribution in modulating $\Delta 6$-desaturase in a favourable way and increases the deposition of n-3 fatty acids in yolks.

Moreover, the fatty acid composition, from the current study, showed that the enrichment with PUFA in eggs was causedd by the increase concentration of total PUFA in the diet, which resulted in an increased accumulation of n-3 and n- 6 PUFA in eggs. The fatty acid composition in eggs directly correlates to the fatty acids consumed by monogastric animals because they are not able to entirely modify the fat consumed during the digestion of food but deposit this fat in eggs, with small modifications.

In this context, the administration of diets high in PUFA is the main tool used to successfully increase the amount of PUFA in eggs (Yi et al., 2014), which represents a wanted effect for today's consumer requests. Current scientific reports show that vegetable by-products, such as RM and FM (with or without antioxidants at moderate levels), could represent a key food ingredient for obtaining enriched foods in order to promote health effects for consumers (Kouba et al., 2011; Vlaicu et al., 2021).

\section{Fatty acid classes of analysed eggs}

A summary of the various fatty acid groups is presented in Table 6. The saturated fatty acids group was significantly lower $(p<0.0026)$ in experimental treatments, the highest concentration being noted in $\mathrm{C}$ treatment. Total MUFA was significantly higher $(p<0.0009)$ in E1 and E2 groups. Also, a significant $(p<0.0009)$ modification in total PUFA and UFA from E1 and E2 eggs, unlike with C group, was observed. The ratios between PUFA/MUFA and SFA/SFA were significantly $(p<0.05)$ lowered in the $\mathrm{E} 1$ and E2 groups, unlike with the $\mathrm{C}$ group. On the other hand, E1 and E2 eggs were significantly $(p<0.0001)$ rich in n-3 PUFA, which resulted in an increase of $59.43 \%, 59.77 \%$ higher than in $\mathrm{C}$ eggs. This resulted in drastic alterations in the $\mathrm{n}-6 / \mathrm{n}-3$ ratio $(p<0.05)$ in egg samples from E1 and E2, unlike with the $\mathrm{C}$ treatment. The obtained results on PUFA/ MUFA and $n-6 / n-3$ ratio are commonly used as indicators for an egg's nutritional value and the 
healthiness of an egg's fat for human consumption.

The increase in the palmitoleic and oleic acid content of the yolks obtained in the E1 and E2 diet variants had the effect of significantly increasing the
MUFA. The same effect had been confirmed previously (Vlaicu et al., 2021) because animal systems only produce SFA and MUFA, but mostly oleic fatty acid.

Table 5 - Fatty acids composition of analysed eggs

\begin{tabular}{lllllc}
\hline Items & $\mathbf{C}$ & E1 & E2 & SEM & $\boldsymbol{p}$ \\
\hline Myristic C14:0 & 0.26 & 0.26 & 0.29 & 0.006 & 0.0217 \\
\hline Myristioleic C14:1 & 0.04 & 0.04 & 0.05 & 0.010 & 0.3066 \\
\hline Pentadecanoic C15:0 & 0.06 & 0.06 & 0.06 & 0.007 & 0.0901 \\
\hline Pentadecenoic C15:1 & 0.11 & 0.09 & 0.10 & 0.020 & 0.2142 \\
\hline Palmitic C16:0 & $23.79^{\mathrm{a}}$ & $22.98^{\mathrm{b}}$ & $23.28^{\mathrm{b}}$ & 0.109 & 0.0022 \\
\hline Palmitoleic C 16:1 & $2.48^{\mathrm{b}}$ & $2.80^{\mathrm{a}}$ & $2.95^{\mathrm{a}}$ & 0.076 & 0.0204 \\
\hline Heptadecanoic C 17:0 & $0.13^{\mathrm{ab}}$ & $0.12^{\mathrm{b}}$ & $0.15^{\mathrm{a}}$ & 0.005 & 0.0363 \\
\hline Heptadecenoic C17:1 & 0.10 & 0.10 & 0.08 & 0.025 & 0.1344 \\
\hline Stearic C18:0 & $11.09^{\mathrm{a}}$ & $10.61^{\mathrm{ab}}$ & $9.97^{\mathrm{b}}$ & 0.202 & 0.0192 \\
\hline Oleic C18:1 & $33.94^{\mathrm{b}}$ & $35.82^{\mathrm{a}}$ & $36.24^{\mathrm{a}}$ & 0.303 & 0.0005 \\
\hline Linoleic C18:2n6 & $20.15^{\mathrm{a}}$ & $18.40^{\mathrm{b}}$ & $19.19^{\mathrm{b}}$ & 0.232 & 0.0020 \\
\hline Linoleic y C18:3n6 & 0.13 & 0.133 & 0.12 & 0.005 & 0.6810 \\
\hline Linoleic a C18:3n6 & $0.23^{\mathrm{c}}$ & $0.91^{\mathrm{b}}$ & $1.07^{\mathrm{a}}$ & 0.090 & $<0.0001$ \\
\hline Eicosadienoic C20:2n6 & 0.20 & 0.16 & 0.16 & 0.009 & 0.0551 \\
\hline Eicosadienoic C20:3n6 & 0.25 & 0.23 & 0.22 & 0.008 & 0.2059 \\
\hline Erucic C22:1n9 & $0.08^{\mathrm{a}}$ & $0.06^{\mathrm{b}}$ & $0.05^{\mathrm{b}}$ & 0.004 & 0.0057 \\
\hline Eicosatrienoic C20:3n3 & 0.23 & 0.22 & 0.22 & 0.005 & 0.4432 \\
\hline Arachidonic C20:4n6 & $4.02^{\mathrm{a}}$ & $3.55^{\mathrm{b}}$ & $3.19^{\mathrm{b}}$ & 0.112 & 0.0027 \\
\hline Nervonic C24:1n9 & $1.35^{\mathrm{a}}$ & $0.39^{\mathrm{b}}$ & $0.33^{\mathrm{b}}$ & 0.013 & $<0.0001$ \\
\hline Docosapentaenoic C22:4n6 & $0.32^{\mathrm{a}}$ & $0.22^{\mathrm{b}}$ & $0.20^{\mathrm{b}}$ & 0.116 & $<0.0001$ \\
\hline Docosapentaenoic C22:5n3 & $0.06^{\mathrm{b}}$ & $0.14^{\mathrm{a}}$ & $0.13^{\mathrm{a}}$ & 0.012 & 0.0002 \\
\hline Docosapentaenoic C22:6n3 & $0.89^{\mathrm{c}}$ & $2.29^{\mathrm{a}}$ & $2.05^{\mathrm{b}}$ & 0.157 & $<0.0001$ \\
\hline Others & $0.05^{\mathrm{b}}$ & $0.41^{\mathrm{a}}$ & $0.11^{\mathrm{b}}$ & 0.041 & $<0.0001$ \\
\hline
\end{tabular}

The symbols used have the same meaning as in Table 3.

Table 6 - Fatty acid classes of analysed eggs

\begin{tabular}{llllll}
\hline Items & $\mathbf{C}$ & E1 & E2 & SEM & $\boldsymbol{p}$ \\
\hline SFA & $35.33^{\mathrm{a}}$ & $34.03^{\mathrm{b}}$ & $33.57^{\mathrm{b}}$ & 0.243 & 0.0026 \\
\hline MUFA & $37.07^{\mathrm{b}}$ & $39.14^{\mathrm{a}}$ & $39.66^{\mathrm{a}}$ & 0.348 & 0.0009 \\
\hline PUFA & $27.56^{\mathrm{a}}$ & $26.41^{\mathrm{b}}$ & $26.66^{\mathrm{b}}$ & 0.191 & 0.0243 \\
\hline UFA & $64.63^{\mathrm{b}}$ & $65.55^{\mathrm{a}}$ & $66.32^{\mathrm{a}}$ & 0.228 & 0.0030 \\
\hline SFA/UFA & $0.55^{\mathrm{a}}$ & $0.52^{\mathrm{b}}$ & $0.51^{\mathrm{b}}$ & 0.006 & 0.0023 \\
\hline PUFA/MUFA & $0.74^{\mathrm{a}}$ & $0.67^{\mathrm{b}}$ & $0.67^{\mathrm{b}}$ & 0.011 & 0.0042 \\
\hline $\mathbf{n}-3$ & $1.44^{\mathrm{b}}$ & $3.55^{\mathrm{a}}$ & $3.58^{\mathrm{a}}$ & 0.245 & $<0.0001$ \\
\hline $\mathbf{n}-6$ & $26.12^{\mathrm{a}}$ & $22.86^{\mathrm{b}}$ & $23.21^{\mathrm{b}}$ & 0.381 & $<0.0001$ \\
\hline $\mathbf{n}-6 / \mathbf{n}-3$ & $18.16^{\mathrm{a}}$ & $6.44^{\mathrm{b}}$ & $6.74^{\mathrm{b}}$ & 1.326 & $<0.0001$ \\
\hline
\end{tabular}

The symbols used have the same meaning as in Table 3. 


\section{CONCLUSIONS}

Based on the data obtained, we conclude that diets containing flaxseed meal and rapeseed meal, with or without vitamin $\mathrm{E}$ as an antioxidant, significantly increased the PUFA concentration in their eggs, especially in n-3 eggs.

We consider it equally necessary to carry out further investigations to establish the influence of dietary ingredients and nutrients on the physical and chemical properties of eggs, sensory characteristics and shelf-life during storage, very important elements for their acceptance by consumers.

Acknowledgement. This study was conducted within project P_40_441 GALIM PLUS - Development of innovative feeding solutions for gallinaceans, with the purpose of producing affordable foods with improved nutritional qualities, funding contract 144/13.10.2016. Project co-funded by the European Union from the European Fund for Regional Development, through the Operational Program Competitiveness 20142020.The content of this material does not necessarily express the official position of the European Union or the Government of Romania.

\section{REFERENCES}

Ahmad, G., Mushtaq, T., Mirza, M.A. \& Ahmed, Z. (2007). Comparative bioefficacy of lysine from L-lysine hydrochloride or L-lysine sulfate in basal diets containing graded levels of canola meal for female broiler chickens. Poult. Sci. 86(3): 525-530, DOI: 10.1093/ps/86.3.525.

Ao, T. et al. (2015). Effects of supplementing microalgae in laying hen diets on productive performance, fatty-acid profile, and oxidative stability of eggs. J. Appl. Poult. Res., 24(3): 394-400, DOI: $10.3382 / j a p r / p f v 042$
AOAC (2005). Official methods of analysis, 18th ed. Washington, DC: Association of Official Analytical Chemists.

Aziza, A.E., Panda, A.K., Quezada, N. \& Cherian, G. (2013). Nutrient digestibility, egg quality, and fatty acid composition of brown laying hens fed camelina or flaxseed meal. J. Appl. Poult. Res., 22(4): 832-841, DOI: 10.3382/japr.2013-00735

Ceylan, N., Ciftçi, I., Mizrak, C., Kahraman, Z. \& Efil, H. (2011). Influence of different dietary oil sources on performance and fatty acid profile of egg yolk in laying hens. J. Anim. Feed Sci., 20(1): 71-83, DOI: 10.22358/jafs/ $66159 / 2011$

Cherian, G. \& Quezada, N. (2016). Egg quality, fatty acid composition and immunoglobulin $Y$ content in eggs from laying hens fed full fat camelina or flax seed. J. Anim. Sci. Biotechnol., 7(1): 15; DOI: 10.1186/s40104-016-0075-y

Domínguez, R., Pateiro, M., Gagaoua, M., Barba, F.J., Zhang, W. \& Lorenzo, J.M. (2019). A comprehensive review on lipid oxidation in meat and meat products. Antioxidants, 8(10): 429, DOI: 10.3390/antiox8100429

FAO/WHO (2010). Food and Agricultural Organization of the United Nations and World Health Organization. Fats and fatty acids in human nutrition. Report of an extract consultation. FAO Food Nutrition Papers: 91, Rome.

Fraeye, I., Bruneel, C., Lemahieu, C., Buyse, J., Muylaert, K. \& Foubert, I. (2012). Dietary enrichment of eggs with omega-3 fatty acids: A review. Food Res. Int., 48(2): 961-969, DOI: 10.1016/ j.foodres.2012.03.014

Gheorghe, A., Vlaicu, P.A., Olteanu, M., Vișinescu, P. \& Criste, R.D. (2019). Obtaining eggs enriched in polyunsaturated fatty acids (PUFA). 1. Use of vegetable sources rich in PUFA as functional ingredients in laying hens diets: A review. Arch. zootech., 22(2): 54-85.

Halle, I. \& Schöne, F. (2013). Influence of rapeseed cake, linseed cake and hemp seed cake on laying performance of hens and fatty acid composition of egg 
yolk. J. Verbrauch. Lebensm., 8(3): 185-193, DOI: 10.1007/s00003-0130822-3

Hayat, Z. et al. (2009). Effect of feeding flax and two types of antioxidants on egg production, egg quality, and lipid composition of eggs. J. Appl. Poult. Res., 18(3): 541-551, DOI: 10.3382/ japr.2009-00008

Imran, M., Anjum, F.M., Nadeem, M., Ahmad, N., Khan, M.K., Mushtaq, Z. \& Hussain, S. (2015). Production of Bio-omega-3 eggs through the supplementation of extruded flaxseed meal in hen diet. Lipids Health Dis., 14(1): 126, DOI: 10.1186/s12944-0150127-x

Irandoust, H., Samie, A.H., Rahmani, H.R., Edriss, M.A., \& Mateos, G.G. (2012). Influence of source of fat and supplementation of the diet with vitamin $E$ and $C$ on performance and egg quality of laying hens from forty four to fifty six weeks of age. Anim. Feed Sci. Technol., 177(s 1-2): 75-85, DOI: 10.1016/j.anifeedsci.2012.06.004

Jiang, W., Zhang, L. \& Shan, A. (2013). The effect of vitamin $E$ on laying performance and egg quality in laying hens fed corn dried distillers grains with solubles. Poult. Sci., 92(11): 29562964, DOI: 10.3382/ps.2013-03228

Khajali, F. \& Slominski, B.A. (2012). Factors that affect the nutritive value of canola meal for poultry. Poult. Sci., 91(10): 2564-2575, DOI: 10.3382/ ps.2012-02332

King, E.J., Hugo, A., de Witt, F.H., van der Merwe, H.J. \& Fair, M.D. (2012). Effect of dietary fat source on fatty acid profile and lipid oxidation of eggs. S. Afr. J. Anim. Sci., 42(5): 503-506, DOI: 10.4314/sajas.v42i5.12

Kirunda, D.F., Scheideler, S.E. \& McKee, S.R. (2001). The efficacy of vitamin E (DL-a-tocopheryl acetate) supplementation in hen diets to alleviate egg quality deterioration associated with high temperature exposure. Poult. Sci., 80(9): 13781383, DOI: $10.1093 / p s / 80.9 .1378$

Kouba, M. \& Mourot, J. (2011). A review of nutritional effects on fat composition of animal products with special emphasis on $\mathrm{n}-3$ polyunsaturated fatty acids. Biochimie, 93(1): 13-17, DOI: 10.1016/j.biochi.2010.02.027

Liu, Y.J. et al. (2019). Protective effect of vitamin $E$ on laying performance, antioxidant capacity, and immunity in laying hens challenged with Salmonella enteritidis. Poult. Sci., 98(11): 58475854, DOI: $10.3382 / p s / p e z 227$

Lordelo, M., Fernandes, E., Bessa, R.J.B. \& Alves, S.P. (2017). Quality of eggs from different laying hen production systems, from indigenous breeds and specialty eggs. Poult. Sci., 96(5): 1485-1491, DOI: 10.3382/ps/pew409

Łukaszewicz, E., Korzeniowska, M., Kowalczyk, A. \& Bobak, Ł. (2007). Effect of feed supplementation with organic selenium and vitamin e on chemical composition and sensory characteristics of japanese quail (Coturnix japonica) eggs. Pol. J. Food Nutr. Sci, 57 (Special issue 4B): 371377.

Mikulski, D., Jankowski, J., Zdunczyk, Z., Juskiewicz, J. \& Slominski, B.A. (2012). The effect of different dietary levels of rapeseed meal on growth performance, carcass traits, and meat quality in turkeys. Poult. Sci., 91(1): 215-223, DOI: 10.3382/ps.2011-01587

Milinsk, M.C., Murakami, A.E., Gomes, S.T.M., Matsushita, M. \& de Souza, N.E. (2003). Fatty acid profile of egg yolk lipids from hens fed diets rich in n3 fatty acids. Food Chem., 83(2): 287292, DOI: 10.1016/S0308-8146(03)00 094-3

Mueller, K., Eisner, P., Yoshie-Stark, Y., Nakada, R. \& Kirchhoff, E. (2010). Functional properties and chemical composition of fractionated brown and yellow linseed meal (Linum usitatissimum L.). J. Food Eng., 98(4): 453-460, DOI: 10.1016/j.jfoodeng.2010. 01.028

Özkan, Y., Yilmaz, Ö., Öztürk, A.İ. \& Erşan, Y. (2005). Effects of triple antioxidant combination (vitamin $\mathrm{E}$, vitamin $\mathrm{C}$ and a-lipoic acid) with insulin on lipid and cholesterol levels and fatty acid composition of brain tissue in 


\section{PROFILE OF FATTY ACIDS AND THE EGGS QUALITY FROM HENS FED WITH FM AND RM}

experimental diabetic and non-diabetic rats. Cell Biol. Int., 29(9): 754-760, DOI: 10.1016/j.cellbi.2005.04.011

Rahimi, M.M. (2014). Effect of sowing date and nitrogen on yield and yield components of medicinal flax. Int. J. Biosci., 5(12): 160-165.

Saini, R.K. \& Keum, Y.S. (2018). Omega-3 and omega-6 polyunsaturated fatty acids: Dietary sources, metabolism, and significance - A review. Life Sci., 203: 255-267, DOI: 10.1016/j.Ifs. 2018.04.049

Sepehr, A., Kashani, R.B., Esmaeili, M., Safari, O. \& Rombenso, A. (2021). Effects of extruded, milled, and whole flaxseed (Linum usitatissimum) on egg performance, lipid components, and fatty acids concentrations in yolk and blood, and antioxidant system of commercial laying hens. Anim. Feed Sci. Technol., 276(1): 114877, DOI: 10.1016/j.anifeedsci.2021.114877

Sigolo, S., Khazaei, R., Seidavi, A., Ayasan, T., Gallo, A. \& Prandini, A. (2019). Effects of supra-nutritional levels of vitamin $E$ and vitamin $C$ on growth performance and blood parameters of Japanese quails. Italian J. Anim. Sci., 18(1): 1-8, DOI: 10.1080/1828051X.2018.1539628

Vlaicu, P.A., Panaite, T.D. \& Turcu, R.P. (2021). Enriching laying hens eggs by feeding diets with different fatty acid composition and antioxidants. Sci. Rep., 11(1): 1-12, DOI: 10.1038/s415 98-021-00343-1

Wołoszyn, J., Haraf, G., Okruszek, A., Wereńska, M., Goluch, Z. \& Teleszko, M. (2020). Fatty acid profiles and health lipid indices in the breast muscles of local Polish goose varieties. Poult. Sci., 99(2): 1216-1224, DOI: 10.1016/j.psj.2019.10.0265

Yi, H., Hwang, K.T., Regenstein, J.M. \& Shin, S.W. (2014). Fatty acid composition and sensory characteristics of eggs obtained from hens fed flaxseed oil, dried whitebait and/or fructo-oligosaccharide. Asian-Australas. J. Anim. Sci., 27(7): 1026-1036, DOI: 10.5713/ajas.2013.13775

(C) 2021 by the authors; licensee Journal of Applied Life Sciences and Environment, lasi, Romania. This article is an open access article distributed under the terms and conditions of the Creative Commons Attribution License (http://creativecommons.org/licenses/by/4.0/). 